\title{
Recycle ineffective buildings on the main streets to solve the housing crisis in Iraq (Street 60 in the Dora area of the city of Baghdad as a case study)
}

\author{
Assisst.Prof.Dr. Saad Khudhair Al-jumaily \\ Al-Nahrain University / College of Engineering /Department of Architecture, PO box 64074, Jadriah, Baghdad, \\ Iraq \\ E-male: Aljumaily.saad@ymail.com
}

\begin{abstract}
:
Most of the buildings that overlook public streets in Iraqi cities, including Baghdad, occupy large areas of land as a result of the horizontal expansion of residential stores. These buildings that shift their use from residential to commercial have become unable to meet the contemporary needs of the community that seeks to be those streets and buildings overlooking it encourage people to move around, shop, entertain, and reduce car use. On the other hand, the age of these buildings that were constructed in the seventies and eighties of the last century has become structurally worn out and their designs are old. The structural coverage of $2.5 \mathrm{~m}$ is half the distance of the recoil to the upper floors. However, those sidewalks for pedestrians and parking lots lack design, furnishing and agriculture, which made them vulnerable to weather conditions and their weaker relationship with those buildings .Those legislations also determined the height of the commercial buildings with three floors and determined the setback of the buildings at the time, which resulted in several problems and these buildings did not meet the needs of contemporary society, so the research aims to study this case to change these legislations and make room for either the owners, developers and financiers to interfere with reconsideration using Those buildings to contribute to solving the housing crisis by increasing the population densities. There is an increasing need for the lands on which these dilapidated buildings were constructed, and these areas were far from the center previously, but now they are part of it. Therefore, this problem and its urban dimensions must be addressed to achieve several goals:

- Verify the quality of the buildings use or suitability for mixed use.

- Recycle land use and ineffective buildings as an economic value.

- Providing additional housing units by adjusting the proportional relationship between street widths and building height.

- Increasing the areas of the upper floors allocated for housing through modify the law of reversion and structural coverage of the upper floors.

- Organizing the building's relationship with the pedestrian and sidewalks movement.

- Encourage owners and developers to reuse these buildings.
\end{abstract}

Key words: urban economy, mixed use, setback, population densities, Building recycling.

DOI: $10.7176 / \mathrm{ADS} / 81-04$

Publication date:April $30^{\text {th }} 2020$

Introduction:

The philosophy of housing in any country is related to the state's philosophy, constitution, and vision to make housing available to the general public to achieve justice and this social balance on the one hand, and on the other hand, its vision includes the outcomes of this view, its urban dimensions, its goals, and its implementation mechanisms.

The prevailing thought in Iraq for the past decades was one-sided thinking. The required justice has been achieved in the individual housing of people and the establishment of some multi-storey housing complexes to achieve social balance because the Iraqi society avoids housing in multi-storey buildings,

Therefore, housing became available, but this view lacks the urban dimensions and the resulting deterioration in the future as a result of the lack of a future view of the urban form that will result from it. Residential horizontally, but it lacks quality, control and efficient management. With the passage of time, these places became inactive and ineffective because they lack densities, mixed use, lack of solidarity of buildings, and also lack all elements of urban sustainability.

Some solutions appeared in the eighties of the last century to address this defect. Specifically, the focus was on shifting the individual residential houses surrounding commercial streets from residential use to commercial use and not a mixed use to organize the urban body by increasing the height of buildings and in most cases it was identified with three floors. Therefore, the situation remained as it is with regard to population and housing 
densities, and the reason is due to the fact that the area of one piece is not sufficient to construct multiple-use buildings in which housing is shared with other activities. This is on the one hand, and on the other hand, legislation specifies that the new buildings should be reverted at a distance of $5 \mathrm{~m}$ from their original borders, which has been cut off approximately $25 \%$ of that area, which made it unsuitable for residential units and not livable and residing in it, Therefore, people abandoned it and the upper floors (first and second) became used as offices, stores, or medical clinics. Accordingly, harmful occupations crawled into these buildings and retail stores and became used for repair and maintenance services, workshops, carpentry works and sale of construction materials.

The inefficiency of the buildings that have expanded in most of the Iraqi streets is a waste of the value of these lands because they are not utilized efficiently, which after recycling their uses and their economic value can contribute to solving the housing problem in Iraq without the need to expand or search for new lands. These buildings constitute a large percentage of the streets of Baghdad and other cities, which are now considered new urban centers after they were suburbs.

\section{The framework:}

\section{Urban Economics: (The Land Values)}

The urban economy focuses on economic relations and processes that are affected by the spatial characteristics of cities and urban areas such as the size of the city, the density of its population, and its internal organization. The urban economy is also concerned with attractive and repulsive forces, economic activities, and populations that may lead to growth, decline, focus, dispersion, preservation, or replacement of any of the urban sites.

Urban economics is broadly the economic study of urban areas; as such, it involves using the tools of economics to analyze urban issues such as crime, education, public transit, housing, and local government finance. More specifically, it is a branch of microeconomics that studies urban spatial structure and the location of households and firms. (1)

In the traditional view, urban areas have a dense central business district with concentrated employment and production, in order to reduce costs of transportation and information sharing. In these so-called monocentric urban areas, land has the highest value in the city center because employment density is highest there. As distance from the city center increases, land and housing prices fall, lot sizes lengthen, workers' commute times' rise, and poverty declines.

All economic activities will attempt to find the best location for the lowest price. Therefore:

- Industries are generally located towards the edge of the city where land prices are low.

- Retail requires the least space, so it is less focused on the price of the land and will locate towards the central business district where the most customers are found.

- Commercial activity is usually found where land values are relatively low per square meter compared to the places used by retail, but as they make enough profit they can still locate in the central business district.

The re-use of land revitalizes communities and renews economic activity, particularly in under-served urban areas. The failure to redevelop brownfields in particular translates into potentially more exposure to toxics and the loss of economic and housing benefits that can come from appropriate redevelopment. (4)

The land recycling indicator comprises two concepts of urban development - land recycling and land densification. 1) Land recycling is defined as the reuse of abandoned, vacant or underused land for redevelopment.

2) Land densification is defined as the land development that takes place within existing communities, making maximum use of the existing infrastructure instead of building on previously undeveloped land.(5)

There are several benefits to recycling and using the value of lands that are not used efficiently, including economic benefits: providing job opportunities for the local community, Compact building, and urban intensification to revitalize the urban environment. Social benefits: intensifying social gatherings and activities, promoting public health, improving quality of life. Finally, the environmental benefits: reduce energy use, improve air quality, reduce dependence on transportation, and protect against weather conditions.

\section{Mixed Use Building:}

A mix of complementary land uses - such as residences, workplaces, and shops - reduces trip distances, thereby making it possible to complete trips by foot or bicycle. Different uses have different peak hours so a variety of activities keeps local streets active at various times of the day. This is vital in ensuring personal safety.(6) Mixeduse is a type of urban development that blends residential, commercial, cultural, institutional, or entertainment uses, where those functions are physically and functionally integrated, and that provide pedestrian connections.(7) Mixed-use buildings are isolated, homogeneous, places that offer few choices, and no relationship to their surrounding environment. (8) Mixed use is the use of a building or set of buildings for more than one 
purpose. Mixed use can combine commercial, industrial, and residential uses on one property. (9) Mixed-use development can take many forms:

- Vertical Mixed-Use: Combines different uses in the same building structure in a distinct vertical fashion.

- Horizontal Mixed-Use: Combines different uses in interconnected building structures in a horizontal fashion.

Vertical mixed-use, which is typified by residential use over commercial uses in the same building. The horizontal mixed-use, combines residential and commercial uses on the same site, but in separate buildings. (11)

\subsection{Benefits of Mixed Use:}

Mixed-use in centers that have increased in population density has allowed people to access places through public transit and has helped encourage walking, biking, and cycling to places of work and errands. (12) To Activates urban areas during more hours of the day, Increases housing options for diverse household types, Reduces auto dependence, Increases travel options and to Creates a local sense of place.(13) Mixed use Benefits are to provide the resident living in upper floors a high quality environment, protect the pedestrian and enhance the pedestrian environment and scale.(14)

\subsection{Building Setback:}

Street is the most important urban element because it serves as the main channel of circulation in the city where people moves and experiencing the city's environment. (15).

A views cape is a visual connection that occurs between a person and the spatial arrangement of urban and landscape features. (16) All Commercial Buildings should be built with appropriate setbacks from the street to maintain a consistent street setback pattern.(17A setback is the minimum distance which a building or other structure must be set back from a street or any other place which is deemed to need protection.(18). Street setbacks combined with building heights and road reserve widths define the proportions and profile of a street and contribute to the character of the public domain.(19) The city center of Baghdad is distinguished by the quality of the buildings setback and the structural coverage of the upper floors.

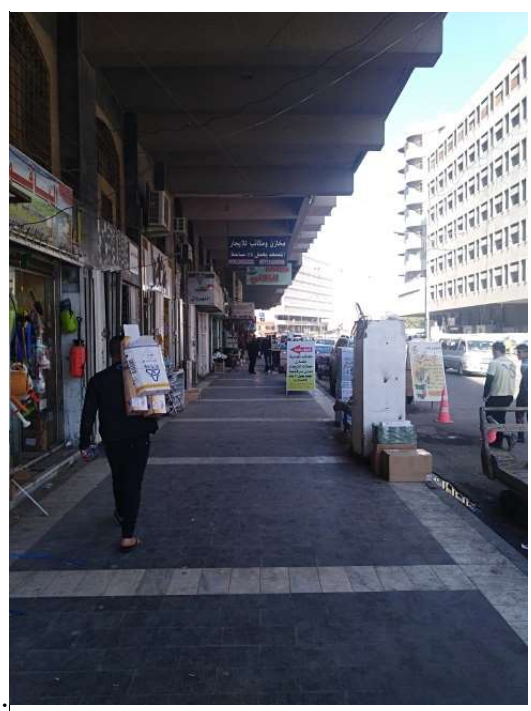

Picture No. (1) Shows the relationship of Setback and structural coverage of the surrounding buildings of AlKhilani Square - Baghdad 


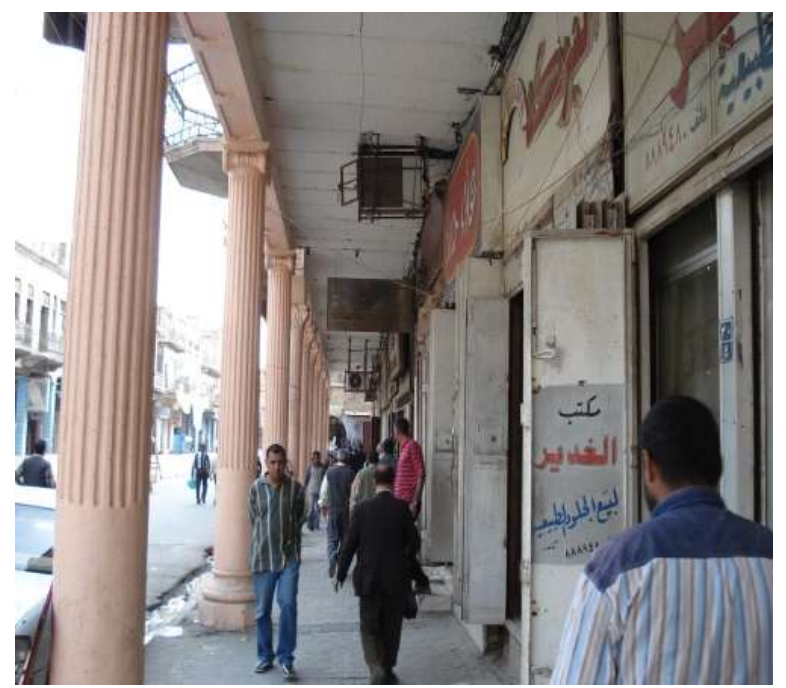

Picture No. (2) Explains the relationship of Setback and building coverage with Al-Rashid Street - Baghdad

After changing the legislation in the eighties of the last century that diverted the use of the main streets of the Surrounding of the city center of Baghdad from residential use to commercial use within stores and residential neighborhoods with a three-story height and a 5-meter setback, the land value of these places was low cost and population density was also low. The pictures below show the height of buildings and the distance setback with her relationship to the street.

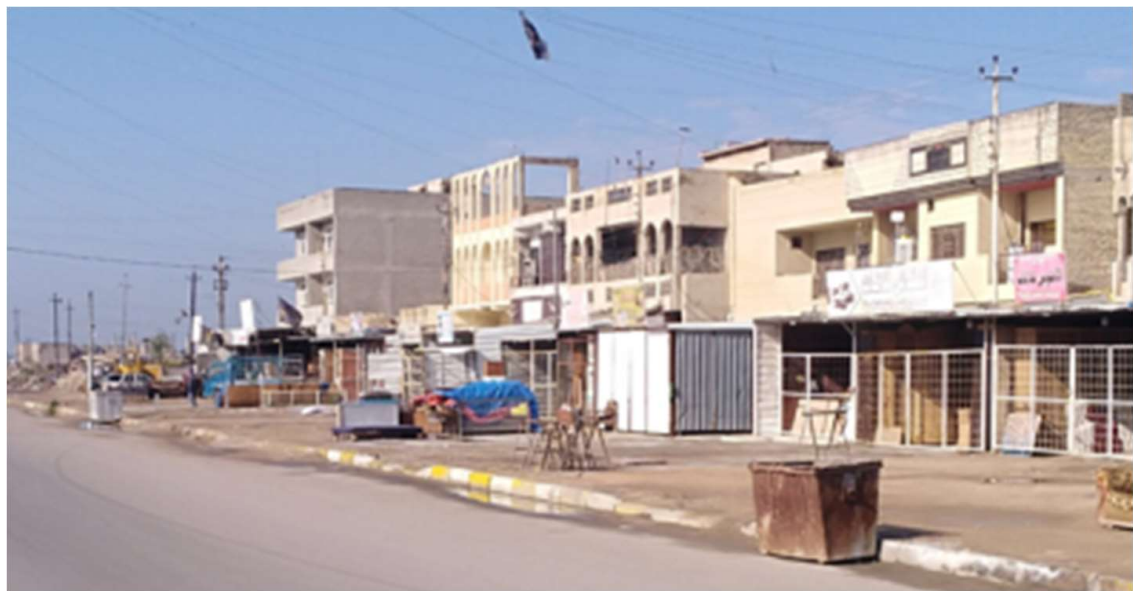

Picture No. (3) Explains the relationship of the buildings with Al-Badalah Street in Baghdad after changing the legislation 


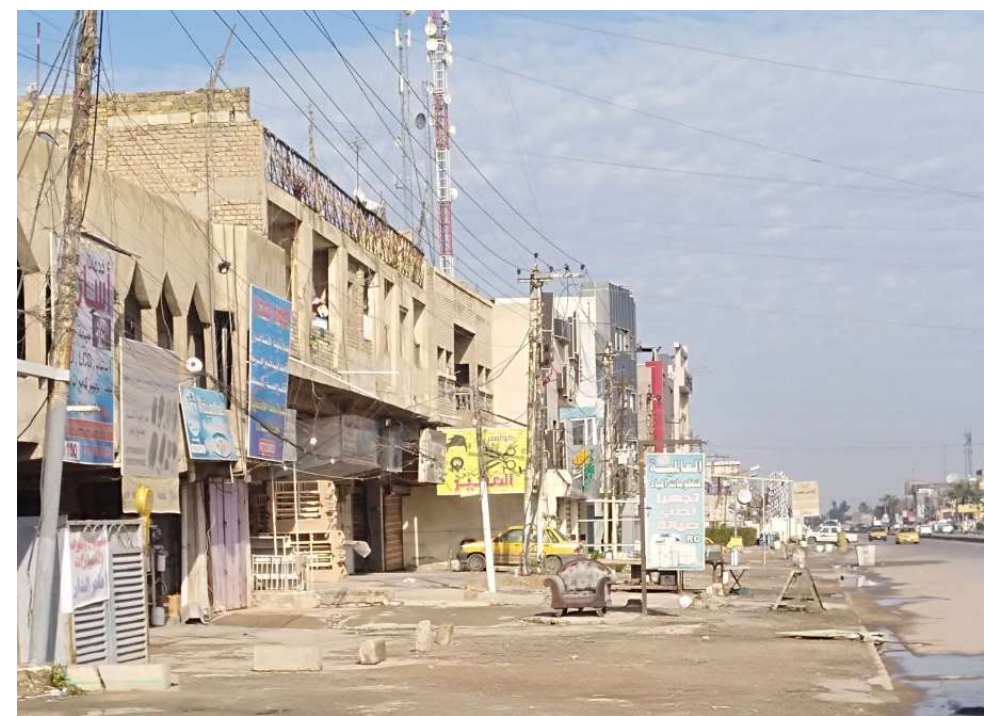

Picture No. (4) Shows the relationship of the buildings with the sidewalk on Baghdad Street, after changing the legislation

\section{Case Study: Street 60 in the Dora area as a case study}

Street 60 was chosen in the Dourah - the Karkh side, as a model for several similar streets in Baghdad and the rest of the major cities in Iraq, and it is a vital street that connects an important area to the Dora area southeast of Baghdad with the capital Baghdad through its intersection with the highway. It is distinguished by its wide width of $60 \mathrm{~m}$, as well as the height of the buildings surrounding it with three floors, and a wide pedestrian pavement plus a distance of $5 \mathrm{~m}$ as a result of the Setback of those buildings from the boundaries of the original pieces according to Iraqi legislation. The problems experienced by the commercial streets in general can be limited to Iraqi cities and this street is precisely in the points shown below:

1. The area of the plots on which the commercial buildings are located is less than 300 square meters, as they were previously intended for housing before they were converted to commercial buildings ... which is a general problem for the Iraqi streets surrounding their centers.

2 .The lack of economic viability for most of the upper floors as it is not habitable.

3. There is no correlation between the heights of commercial buildings and the width of the streets overlooking them.

4. The weak activities and events of the streets, as they lack residential densities and depend on the neighboring residential shops, which are only two stories high.

5. Lacking public and private transportation due to weak population densities.

6. Urban landscape deteriorated due to inefficiency of recoil and irregular sky line.

7. Variation of building heights surrounding the street, some of which are still private housing with one or two floors and three floors for commercial buildings.

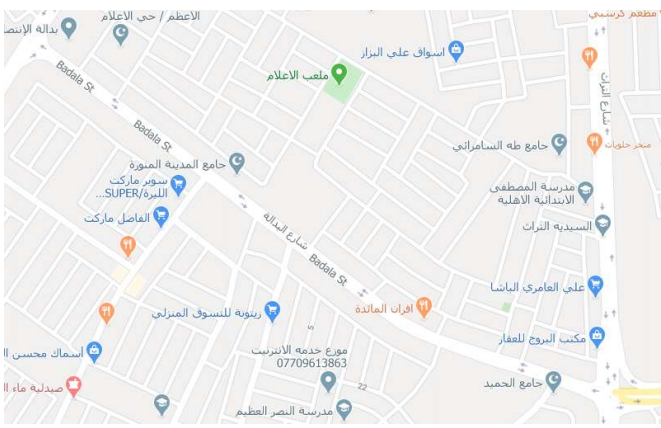

Map No. (1) Shows the location of the street in relation to the Baghdad city 


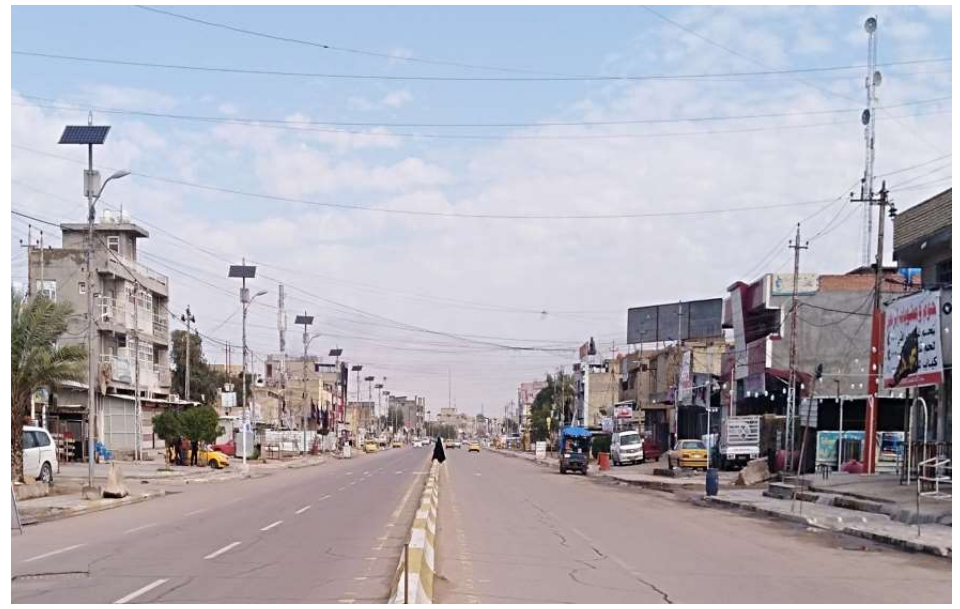

Picture No. (5) Shows the urban scene of Street 60 in the Dora-Baghdad Area

The efficiency of the commercial buildings surrounding Street 60 in the Dora area, to the southeast of Baghdad, will be verified through three axes: buildings mixed -use, Setback of commercial buildings, and population densities.

The first axis: Measuring the efficiency of buildings mixed-use:

The views of the architects residing in Baghdad city were explored by answering the following questions regarding the measurement of mixed use of commercial buildings surrounding Street 60 in the Dora area of Baghdad:

1. Do you feel mixed use on commercial streets?

2. Are the existing buildings of high quality to meet of society needs?

3. Do these buildings encourage strangers from other regions to visit?

4. Do you feel safe, comfortable seeing and using the existing buildings of these streets?

5. Are there attractive activities for existing buildings that encourage people to move to and move around them?

6. Are the floors of the existing buildings diverse to use?

7. Do existing buildings encourage people to enter and use them?

8. Do you feel the presence of distinctive buildings that are important attractions for the general public?

9. Do these streets operate during daylight hours and extend late into the night?

\section{Evaluation results:}

Table No. (1) Shows results of evaluation of mixed use of buildings surrounding the street.

\begin{tabular}{|c|c|c|c|c|c|c|}
\hline \multirow{11}{*}{ 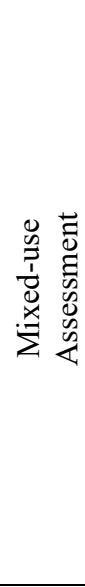 } & \begin{tabular}{l}
$\dot{0}$ \\
$z$ \\
\multirow{0}{\Xi}{}
\end{tabular} & $\begin{array}{l}\tilde{y} \\
\dot{\Xi} \\
\frac{\tilde{J}}{\tilde{E}} \\
3\end{array}$ & 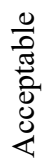 & 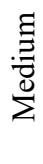 & $\begin{array}{l}\overline{8} \\
8 \\
\end{array}$ & $\begin{array}{l}\overrightarrow{8} \\
0 \\
0 \\
0 \\
0 \\
j\end{array}$ \\
\hline & \multicolumn{6}{|c|}{ Results } \\
\hline & 1 & 8 & 6 & 2 & 1 & 3 \\
\hline & 2 & 13 & 3 & 1 & 1 & 2 \\
\hline & 3 & 9 & 1 & - & 5 & 4 \\
\hline & 4 & 16 & - & 2 & 2 & - \\
\hline & 5 & 14 & 4 & 2 & - & - \\
\hline & 6 & 10 & 6 & 4 & - & - \\
\hline & 7 & 9 & 8 & 1 & 1 & 1 \\
\hline & 8 & 11 & 3 & 3 & 2 & 1 \\
\hline & 9 & 12 & 3 & 3 & 1 & 1 \\
\hline
\end{tabular}

Table No. (1) Shows the Results of the Mixed-use Assessment 


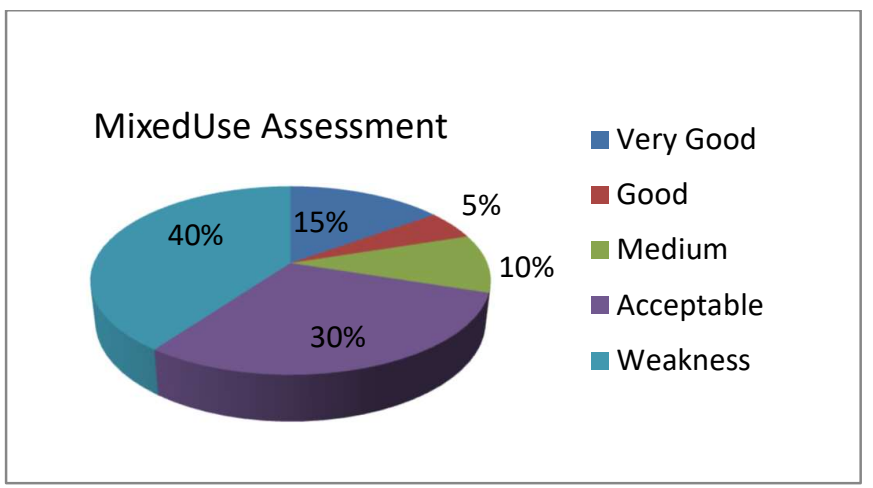

Diagram No. (1) Shows the Result Percentages of Mixed-use Assessment

The second Axis: measuring the efficiency of Commercial Buildings Setback

The views of the architects residing in the city of Baghdad were explored by answering the following questions regarding measuring the efficiency of the commercial buildings Setback surrounding Street 60 in the Dora area of Baghdad.

1. Do you think that the remaining space after the building Setback at a distance of $5 \mathrm{~m}$ from the commercial plot is not sufficient to design apartments?

2. Do you think that the emergence of upper floors of $2.5 \mathrm{~m}$, is not enough to design apartments with an area of more than 75 Square meters?

3. Do you think the emergence of the upper floors is proportional to the width of the street?

4. Do you think the emergence of the upper floors is proportional to the size of the building?

5. Do you think setback and the emergence contributed to organizing the building's relationship with the street?

6. Do you think the distance of setback plus the sidewalk width is designed for parking?

7. Does the setback contribute to increasing the space of the street exposed to the sun?

8. Do you think the setback distance hinders the design of housing units?

9. Do you think the setback contributed to reducing the number of housing units?

10. Do you feel environmental protection and comfort when moving between these buildings?

\section{Assessment results:}

Table No. (2) Shows the results of the efficiency of building setback from the street.

\begin{tabular}{|c|c|c|c|c|c|c|}
\hline \multirow{12}{*}{ 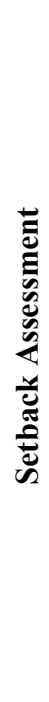 } & 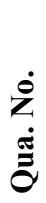 & 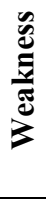 & $\frac{\frac{0}{2}}{\frac{\pi}{0}}$ & $\underset{\Xi}{\Xi}$ & 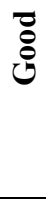 & 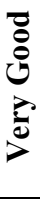 \\
\hline & & \multicolumn{5}{|c|}{ Results } \\
\hline & 1 & 7 & 2 & 4 & 3 & 4 \\
\hline & 2 & 5 & 4 & 3 & 1 & 5 \\
\hline & 5 & 8 & 3 & 3 & 3 & 3 \\
\hline & 4 & 8 & 4 & - & 5 & 4 \\
\hline & 5 & 3 & 1 & 5 & 8 & 3 \\
\hline & 6 & 7 & 5 & 5 & 2 & 1 \\
\hline & 7 & 3 & 1 & 4 & 7 & 5 \\
\hline & 8 & 8 & 3 & 2 & 3 & 4 \\
\hline & 9 & 2 & 9 & 3 & 3 & 3 \\
\hline & 10 & 9 & 3 & 4 & 1 & 3 \\
\hline
\end{tabular}

Table No. (2) Shows the Results of the Building Setback Assessment 


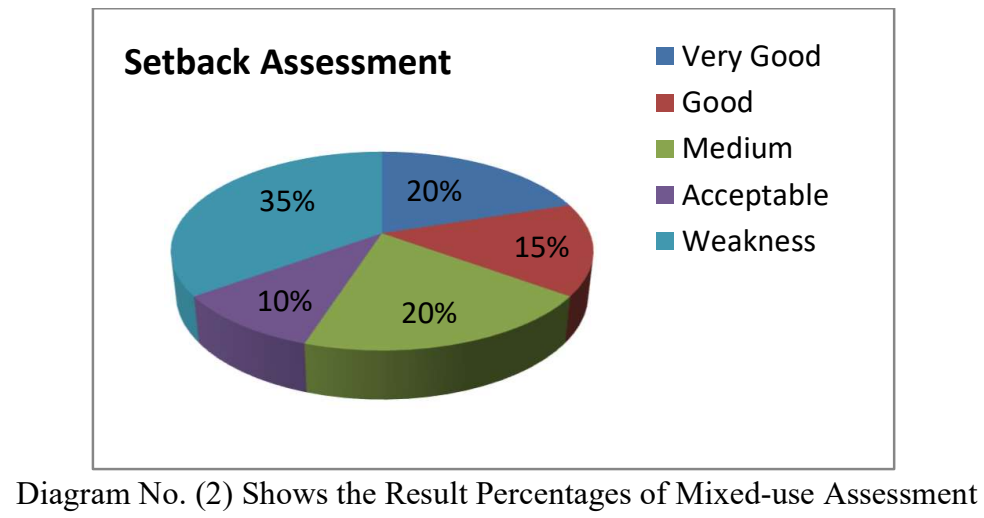

The Third Axis: Assessment population densities of the buildings surrounding the street

The opinion of the architects residing in the city of Baghdad was explored by answering the following questions regarding the measurement of population densities in Street 60 in the Dora area of Baghdad:

1. Do you feel that the densities of the commercial streets are weak?

2. Do you feel the population density of the commercial streets is high?

3. Is there trading of residential units with separate bonds?

4. Does the current law of setback and structural coverage encourage changing the uses of buildings from office units to habitable units?

5. Does the presence of existing buildings encourage financing and investment?

6. Do you think that the value of the land on which these buildings were built has been well utilized?

7. Do you feel that the current buildings are suitable for residential use?

\section{Assessment results:}

Table No. (3) shows the Assessment results of the population density of this street?

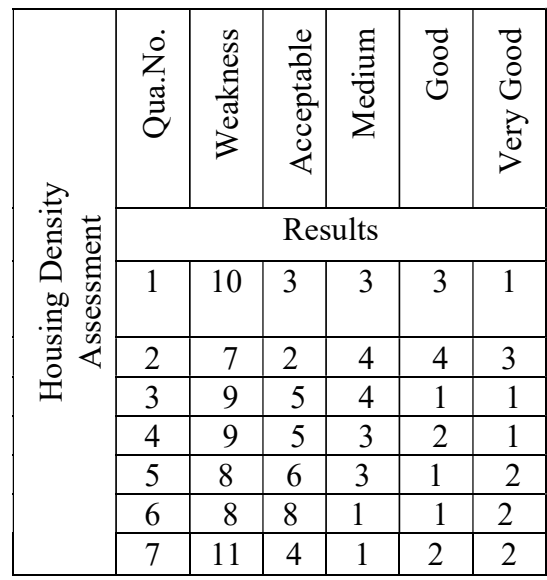

Table No. (3) Shows the Results of the Housing Density Assessment 


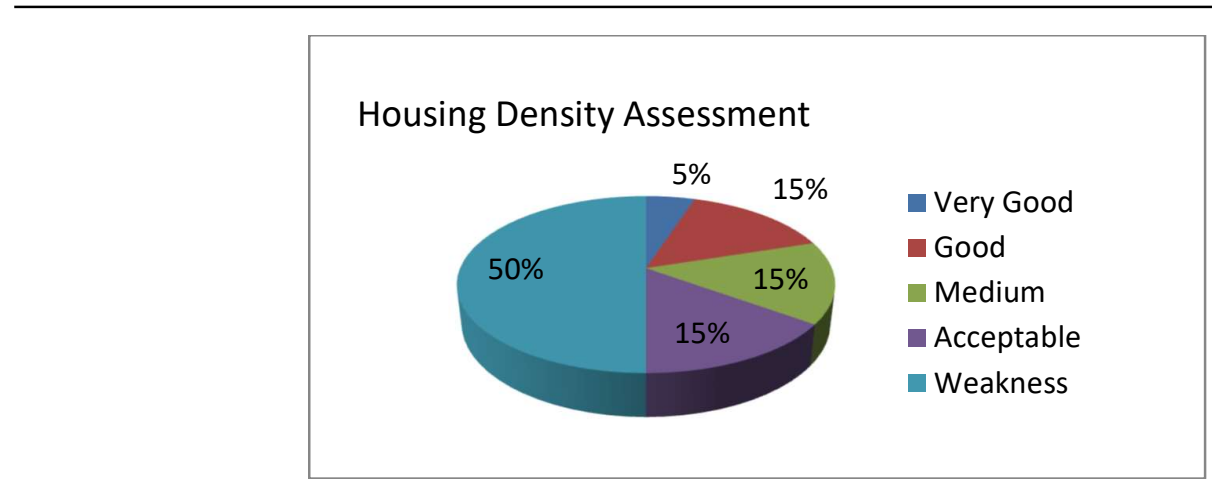

Diagram No. (3) Shows the Result Percentages of the Housing Density Assessment

\section{Discuss the results:}

The results of the field study of Street 60 in the Dora area in Baghdad showed the following results:

1. The results of mixed use of buildings Assessments:

The results of the mixed use Assessments of buildings surrounding the street indicate that the street lacks the characteristics of mixed use that combine housing, trade and contemporary retail stores. The mixed and weak mixed use ratio was $70 \%$, and the average Assessment rate was $10 \%$, the total of the weak, acceptable, and average Assessment becomes $80 \%$, which is the ratio Very high indicating that the use of the buildings surrounding the street, is not sufficient for the local community to carry out various activities, as it was intended for the movement of cars and the service of the residential shops surrounding it only and was not planned for other urban goals.

2. Results of Assessing the setback of buildings surrounding the street:

The results of the Assessing of the buildings setback from the street indicate that the relationship of the setback distance to the street, the sidewalk was weak and acceptable at $45 \%$. The average Assessment rate was $20 \%$, therefor the total of the weakness, acceptable and medium Assessment are 65\%. Which it's a large percentage indicating the inefficiency of this law as it did not take into account the width of the current street, and this 5-meter bounce has increased the space of the street and sidewalk, as it is increased the area exposed to the sun.

\section{Results of the population densities Assessments:}

The population density Assessment results of the street and the surrounding buildings indicate that the Assessment is weak at 50\%, and if an acceptable evaluation percentage is added at $15 \%$, the final result will be $65 \%$ as well. It is a clear result indicating that the buildings surrounding the street were intended for single residential use and the area of land does not exceed $250 \mathrm{~m}^{2}$ and are not intended for mixed use. Also, the decision to convert the use of buildings surrounding wide streets into commercial use allows owners to rise to only three floors, lacking to the future visibility and the proportional relationship between building height and street width.

\section{Conclusion:}

As a summary of this study, it is necessary to follow the following points due to its importance to address the problems experienced by these streets, which are many in Iraqi cities for the same reasons above, and that these treatments will contribute to recycling the value of lands to stimulate the street and increase the population densities and make the street for mixed use and improve the relationship of the buildings with the street and the sidewalk And users, these points are:

1. Modify the law of commercial buildings setback, to ensure the return of the original area of the property amounting to $5 \mathrm{~m}$, and its limits being property rights, to ensure an increase in the area of upper floors.

2. Increasing the areas of apartments for typical floors to encourage owners to recycle the value of the land, demolish and rebuild it, and provide a gallery to protect people from the weather conditions.

3. Allowing the circulation of these housing Units and selling them with separate bonds (sorting Units).

4. Participation of investors and banks in supporting and participating owners, to encourage them to demolish and rebuild according to the new regulations.

5. Increase the height of buildings located on both sides of the street to achieve the minimum concept of space containment of the street.

6. Providing sufficient areas for the establishment of habitable apartments instead of office apartments.

7. Getting rid of the inefficient buildings and rebuilding them to solve the problem of housing and organizing the heights of the buildings surrounding the street to organize the urban landscape and reduce the areas exposed to the sun in the street space.

8. Revitalizing the street and providing job opportunities for the community by increasing the population densities. 
9. Provide safe and sustainable paths by organizing the relationship of buildings with the pedestrians.

\section{References:}

1. From Wikipedia, the free encyclopedia.

2. Janet Rothenberg Pack, Samara Potter, and William G. Gale; " The New Urban Economy: Opportunities and Challenges"; report, Friday, June 1, 2001.

3. Burdettm, Matt;" Urban economic activities", GeographyCaseStudy.Com, 17 March 2019.

4. Land recycling, From Wikipedia, the free encyclopedia

5. Land recycling and densification" European Environment Agency, 2018. www.eea.europa.eu.

6. UN-Habitat \& Institute for Transportation and Development Policy;" Streets for walking \& cycling Designing for safety, accessibility, and comfort in African cities", 2018.

7. From Wikipedia, the free encyclopedia.

8. Sanya,Aluko Olawale, "Improving Human-building performance in Mixed-Use High-Rise Building through livability character", International Journal of Scientific Research and Innovative Technology ISSN: 2313-3759 Vol. 5 No. 1; January 2018.

9. Institute for Public policy and Economic Development;" Mixed Use Development"; May 2013. www.nepahousing.org > pdfs > mixed-use.

10. Restore: Commercial and mixed use development trends in the rocky mountain west.

11. City of Antioch citywide design guidelines manual.

12. From Wikipedia, the free encyclopedia

13. Miller, Nancy; Miller, Jeff " Defining Mixed-use Development", Design Center for American Urban Landscape Design Pointer, Number 3 / December 2003.

14. City of Antioch citywide design guidelines manual

15. Hartanti, Nurhikmah Budi \& Martokusumo, Widjaja; "Streetscape Character As Representation of Urban Identity Case Study: Bogor", Conference: Great Asian Street Symposium, At National University of Singapore, 2014.

16. Lise Burcher, Urban Character and Viewscape Assessment, ISoCaRP Congress 2005.

17. Commercial Guidelines Provide appropriate setbacks.

18. From Wikipedia, the free encyclopedia, Setback (land use).

19. "Gold Coast City Plan Study Setbacks and Site Cover In Medium and High Density Residential Zones", Prepared For City Of Gold Coast December, 2017. https: //www.goldcoast.qld.gov.au/documents/bf/ 


\section{Appendix No. (1)}

Assessment the quality of the commercial streets in the areas surrounding Baghdad city center

\begin{tabular}{|c|c|c|c|c|c|c|}
\hline \multirow[b]{2}{*}{ 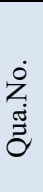 } & \multirow[b]{2}{*}{ Mixed-use Assessment } & \multicolumn{5}{|c|}{ Assessment } \\
\hline & & $\begin{array}{l}0 \\
\tilde{d} \\
\tilde{\Xi} \\
\bar{\Xi} \\
\dot{z}\end{array}$ & 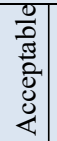 & 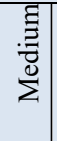 & \begin{tabular}{l|l} 
\\
$\dot{0}$ \\
$\dot{0}$
\end{tabular} & $\begin{array}{l}\overrightarrow{8} \\
8 \\
0 \\
3 \\
\overrightarrow{0} \\
>\end{array}$ \\
\hline 1 & Do you feel mixed use on commercial streets? & & & & & \\
\hline 2 & Are the existing buildings of high quality to meet of society needs? & & & & & \\
\hline 3 & Do these buildings encourage strangers from other regions to visit? & & & & & \\
\hline 4 & $\begin{array}{l}\text { Do you feel safe, comfortable seeing and using the existing buildings of } \\
\text { these streets? }\end{array}$ & & & & & \\
\hline 5 & $\begin{array}{l}\text { Are there attractive activities for existing buildings that encourage people } \\
\text { to move to and move around them? }\end{array}$ & & & & & \\
\hline 6 & Are the floors of the existing buildings diverse to use? & & & & & \\
\hline 7 & Do existing buildings encourage people to enter and use them? & & & & & \\
\hline 8 & $\begin{array}{l}\text { Do you feel the presence of distinctive buildings that are important } \\
\text { attractions for the general public? }\end{array}$ & & & & & \\
\hline 9 & $\begin{array}{l}\text { Do these streets operate during daylight hours and extend late into the } \\
\text { night? }\end{array}$ & & & & & \\
\hline \multicolumn{7}{|c|}{ Setback Assessment } \\
\hline 1 & $\begin{array}{l}\text { Do you think that the remaining space after the building Setback at a } \\
\text { distance of } 5 \mathrm{~m} \text { from the commercial plot is not sufficient to design } \\
\text { apartments? }\end{array}$ & & & & & \\
\hline 2 & $\begin{array}{l}\text { Do you think that the emergence of upper floors of } 2.5 \mathrm{~m} \text {, is not enough } \\
\text { to design apartments with an area of more than } 75 \text { Square meters? }\end{array}$ & & & & & \\
\hline 3 & $\begin{array}{l}\text { Do you think the emergence of the upper floors is proportional to the } \\
\text { width of the street? }\end{array}$ & & & & & \\
\hline 4 & $\begin{array}{l}\text { Do you think the emergence of the upper floors is proportional to the size } \\
\text { of the building? }\end{array}$ & & & & & \\
\hline 5 & $\begin{array}{l}\text { Do you think setback and the emergence contributed to organizing the } \\
\text { building's relationship with the street? }\end{array}$ & & & & & \\
\hline 6 & $\begin{array}{l}\text { Do you think the distance of setback plus the sidewalk width is designed } \\
\text { for parking ? }\end{array}$ & & & & & \\
\hline 7 & $\begin{array}{l}\text { Does the setback contribute to increasing the space of the street exposed } \\
\text { to the sun? }\end{array}$ & & & & & \\
\hline 8 & Do you think the setback distance hinders the design of housing units? & & & & & \\
\hline 9 & $\begin{array}{l}\text { Do you think the setback contributed to reducing the number of housing } \\
\text { units? }\end{array}$ & & & & & \\
\hline 10 & $\begin{array}{l}\text { Do you feel environmental protection and comfort when moving between } \\
\text { these buildings? }\end{array}$ & & & & & \\
\hline \multicolumn{7}{|c|}{ Housing Density Assessment } \\
\hline 1 & Do you feel that the densities of the commercial streets are weak? & & & & & \\
\hline 2 & Do you feel the population density of the commercial streets is high? & & & & & \\
\hline 3 & Is there trading of residential units with separate bonds? & & & & & \\
\hline 4 & $\begin{array}{l}\text { Does the current law of setback and structural coverage encourage } \\
\text { changing the uses of buildings from office units to habitable units? }\end{array}$ & & & & & \\
\hline 5 & $\begin{array}{l}\text { Does the presence of existing buildings encourage financing and } \\
\text { investment? }\end{array}$ & & & & & \\
\hline 6 & $\begin{array}{l}\text { Do you think that the value of the land on which these buildings were built } \\
\text { has been well utilized? }\end{array}$ & & & & & \\
\hline 7 & Do you feel that the current buildings are suitable for residential use? & & & & & \\
\hline
\end{tabular}

